\title{
Wagner's Law in Sri Lanka: An Econometric Analysis
}

\author{
Mayandy Kesavarajah \\ Department of Economics, University of Colombo, Colombo 00300, Sri Lanka \\ Correspondence should be addressed to Mayandy Kesavarajah, makesavan14@gmail.com
}

Received 19 August 2012; Accepted 20 September 2012

Academic Editors: B.-L. Chen, C. Le Van, and M. Tsionas

Copyright ( $) 2012$ Mayandy Kesavarajah. This is an open access article distributed under the Creative Commons Attribution License, which permits unrestricted use, distribution, and reproduction in any medium, provided the original work is properly cited.

\begin{abstract}
This study examines whether there is empirical evidence that Wagner's law holds in the Sri Lankan economy using time series annual data over the period from 1960 to 2010 for Sri Lanka, applying cointegration and error correction modeling (ECM) techniques. In particular, this study keeps a special focus to examine the validity of six versions of Wagner's hypothesis, which support the existence of long-run relationship between public expenditure and economic growth. The empirical evidence of this study indicates that while there prevail is a short-run relationship between public expenditure and economic growth, the longrun results showed no strong evidence in support of the validity of the Wagner's law for Sri Lankan economy. Granger causality analysis also confirms this result. Therefore, the findings of this study pave to broaden this study further for a deeper understanding about the relationship between public expenditure and economic growth by giving more attention on individual items of public expenditure and by including more macroeconomic variables in the econometric model using different methodology in future.
\end{abstract}

\section{Introduction}

Fiscal policy is a fundamental instrument that can be used to lessen short-run fluctuations in output and employment. Meanwhile, in macroeconomic issues such as high unemployment, inadequate national savings, excessive budget deficits, and large public debt burdens, fiscal policy has been acknowledged to hold center stage in policy debate in both developed and developing economies. During the global economic recession of the 1930 s, the government sectors of both developed and developing economies played a vital role in stimulating economic growth and development, as advocated by Keynes. In such situations every economy attempted to promote its economic growth through increasing government expenditures and reducing taxes. These empirical achievements and the Keynesian theoretical outpourings generated considerable interest among economists and policy makers to the issues of fiscal policy as a stabilising force. Public expenditure is a fundamental instrument that influences the sustainability of public finances via effects on fiscal balances and government debt. Moreover, public expenditure can also pursue other objectives, including output, employment, and redistribution, which can contribute to economic welfare. On the other hand, tax policy can also be used to achieve the fiscal policy goals of fair distribution of income and wealth, efficient resource allocation, economic stabilization, and so on, [1]. Taxes affect economic growth rates in numerous ways: discouraging savings and investment decision made by individuals and firms and entrepreneurship, discouraging work effort, workers' acquisition of skills, and so on.

Although the financing of government expenditure can be growth retarding, in general, the provision of social and physical infrastructure through government expenditure can improve productivity through a more efficient allocation of resources. Therefore, issues relating to criteria for the allocation of government expenditure among different sectors and implementing appropriate tax policies are of special policy relevance, since they are directly related with the country's economic growth and development. However, in the recent decades, these empirical achievements and the Keynesian theoretical outpourings generated considerable interest among economists and policy makers to the issues of relationship between public expenditure and economic growth.

On the theoretical front, however, there are two main strands of theories that are prevailing in economic literature regarding the relationship between public expenditure and 
economic growth. First one is Wagner's hypothesis or Wagner's Law [2], and second is Keynesian hypothesis [3]. These two theories perceive the functional relationship between these two variables under a different perspective. Wagner's hypothesis or Wagner's law highlight that public expenditure is an endogenous factor that is driven by the growth of national income. In contrast, Keynesian hypothesis emphasizes that economic growth occurs as a result of rising public expenditure and is considered as an independent exogenous variable to influence the economic growth. Furthermore, while Wagner's law establishes that the causality is running from economic growth to public expenditure, but, in Keynesian theory, the direction of causality is running from public expenditure to economic growth. Hence, these two theories are fundamentally different due to the causal relationship between public expenditure and economic growth.

While there are a number of studies $[4,5]$ that have estimated the relationship between public expenditures and economic growth, there is no clear consensus among these studies on the exact relationship between these two variables. Hence, this paper takes an important step in the above direction to contribute to the existing literature by shedding light on the relationship between public expenditures and economic growth of small open economy of Sri Lanka by using time series econometrics techniques over the period from 1960 to 2010 .

The paper is structured as follows. Section 2 briefly reviews the theoretical explanations and empirical literature on Wagner's law. Section 3 provides an overview of public expenditure and economic growth in Sri Lanka. Further the data on public expenditure in Sri Lanka with regional perspective is also discussed in this section. Section 4 brings out the sources of data and methodological framework adopted in the study to test Wagner's hypothesis in more detail. The Section 5 presents the empirical evidences from time series perspectives. This will give a more quantitative insight. The Section 6 summarizes the major findings of the study and suggests avenue for future research.

\section{Literature Review}

2.1. Wagner's Law: A Theoretical Framework. The relationship between public expenditure and economic growth has been examined by many authors in both developed and developing countries of the world. However the results derived from many researchers have shown various conclusions and have created serious debate among scholars. Adolph Wagner formulated the law of increasing public expenditures in 1893 which is popularly known as Wagner's hypothesis or Wagner's law. The law suggests that the share of the public sector in the economy will rise as economic growth proceeds, owing to the intensification of existing activities and extension of new activities. Wagner observed the existence of relationship between economic growth and public expenditure. The primary idea behind this relationship is that the growth in public expenditure is a natural consequence of economic growth. Accordingly, public expenditure is an endogenous factor that is driven by the growth of national income.
Further, Wagner's hypothesis emphasizes that, in the process of economic development, government economic activity increases relative to private economic activity. Wagner offered three reasons why this would be the case. First, with economic growth industrialization and modernization would take place which will diminish the role of public sector for private one. This continuous diminishing share of the public sector in economic activity leads to more government expenditure for regulating the private sector. Second, the rise in real income would lead to more demand for basic infrastructure particularly education and health facilities. Wagner asserts that it is the government who provides these facilities more efficiently than private sector. And third, to remove monopolistic tendencies in a country and to enhance economic efficiency in that sector where large amount of investment is required, government should come forward and invest in that particular area which will again increase public expenditure [6].

However, in the Keynesian paradigm [3], economic growth occurs as a result of rising public expenditure and is considered as an independent exogenous variable to influence the economic growth. While according to Wagner's approach causality runs from output to public expenditure, the Keynesian approach assumes that causality runs from public expenditure to output. Both the Wagner's hypothesis and Keynesian hypothesis are short-run phenomenon in which the causality testing approach does help to identify the short-run interaction between public expenditure and economic growth. Wagner's law contains six versions which have been empirically tested by different economists over the years. Despite Wagner did not present his hypothesis in mathematical form, over the decades, different economists have used different mathematical model for testing this hypothesis. Specifically, there are six versions of this law that have been empirically tested by different economists.

Peacock and Wiseman [7] used the following double $\log$ equation to estimate the elasticity. According to them, growth in real government expenditure (RGE) is dependent upon the growth in real GDP. We have

$$
\ln \mathrm{RGE}_{t}=a_{1}+b_{1} \ln \left(\mathrm{RGDP}_{t}\right)+u_{1 t} .
$$

Gupta [8] used different model to test the validity of Wagner's law by accounting the increase in population. He affirmed that growth in real per-capita government expenditure $(\mathrm{RGE} / P)$ is dependent upon the growth in real GDP per capita $(\mathrm{RGDP} / \mathrm{P})$. Consider

$$
\ln \left(\frac{\mathrm{RGE}_{t}}{\mathrm{P}_{t}}\right)=a_{2}+b_{2} \ln \left(\frac{\mathrm{RGDP}_{t}}{\mathrm{P}_{t}}\right)+u_{2 t} .
$$

Goffman [9] used another mathematical form, known as the absolute version of the law, where he emphasized that real government expenditure (RGE) is dependent upon the growth in real GDP per capita $(\mathrm{RGDP} / P)$. Consider

$$
\ln \left(\mathrm{RGE}_{t}\right)=a_{3}+b_{3} \ln \left(\frac{\mathrm{RGDP}_{t}}{\mathrm{P}_{t}}\right)+u_{3 t} .
$$

Pryol [10] gave similar explanation by using government consumption expenditure (GCE) instead of total 
government expenditure (GE) as a dependent variable. This mathematical version, however, did not take into account the effect of increase in population. We have

$$
\ln \left(\mathrm{GCE}_{t}\right)=a_{4}+b_{4} \ln \left(\mathrm{GDP}_{t}\right)+u_{4 t} .
$$

R. A. Musgrave and P. B. Musgrave [1] has explained that growth in the share of nominal government expenditures in nominal GDP (NGE/NGDP) depends upon the real GDP per capita $(\mathrm{RGDP} / \mathrm{P})$. Cosider

$$
\ln \left(\frac{\mathrm{NGE}_{t}}{\mathrm{NGDP}_{t}}\right)=a_{5}+b_{5} \ln \left(\frac{\mathrm{RGDP}_{t}}{\mathrm{P}_{t}}\right)+u_{5 t} .
$$

Mann [11] interpreted the law in relative sense. He used the real GDP instead of real GDP per capita as an independent variable. According to him, nominal government expenditures in nominal GDP (NGE/NGDP) depend upon real GDP as follows:

$$
\ln \left(\frac{\mathrm{NGE}_{t}}{\mathrm{NGDP}_{t}}\right)=a_{6}+\ln \left(\mathrm{RGDP}_{t}\right)+u_{6 t} .
$$

This study attempts to test the validity of all six versions of Wagner's law in case of Sri Lanka during the period from 1960 to 2010.

2.2. Empirical Studies. Wagner's hypothesis has received wide attention from economists, and many empirical investigations of its validity in both developed and developing economies have yielded mixed results. Ranjan and Sharma [12] examined the effect of public expenditure on economic growth during the period from 1950 to 2007 in India. They found a significant positive impact of public expenditure on economic growth. They also reported an existence of cointegration among the variables. Singh and Sahni [13] used Granger causality test to determine the causality direction between national income and public expenditures in India. Aggregate as well as disaggregate expenditure data for the period of 1950 to 1981 was used. Data used in the study were annual and deflated by using implicit national income deflator. The study finds no causal relationship confirming the Wagnerian law or the opposite view.

Castles and Dowrick [14] used the shares of disaggregated public expenditure in health, education, and social transfers to explain economic growth. They found that social transfers and education had a positive effect on growth. Devarajan et al. [15] also assessed the impact of different types of public expenditure on economic growth, but they did not find any significant relationship. Dogan [16] investigated the relationship between national income and public expenditures for Indonesia, Malaysia, Philippines, Singapore, and Thailand. Granger causality tests were used to investigate the causal links between the two variables. The result of Granger causality revealed that causality runs from public expenditures to national income only in the case of Philippines, and there was no evidence for other countries.

Verma and Arora [17] examined the validity of Wagner's law in India over the period from 1951 to 2008. Empirical evidences regarding short-run dynamics refuted the existence of any relationship between economic growth and the size of the government expenditure. Afzal and Abbas [18] reinvestigated the application of the Wagner's hypothesis to Pakistan over the period from 1960 to 2007 using time series econometrics techniques. The study found that Wagner's hypothesis does not hold for aggregate public spending and income for three periods (1961-2007, 1973-1990, and 1991-2007) while it holds only for the period from 1981 to 1991. However, when fiscal deficit is included, the results supported the existence of Keynesian views about public spending and growth.

Zheng et al. [19] studied the empirical analysis on the relationship between the size of Chinese government, as measured by its annual spending, and the growth rate of the economy. More specifically, it designed to examine the applicability of Wagner's law to the Chinese economy. The statistics used in this research is annual time series data on total government spending and gross domestic product covering the period from 1952 to 2007. Empirical results showed no strong evidence in support of the validity of Wagner's law for Chinese economy. Olomola [20] confirmed the Wagner's hypothesis both in short run and in the long run in Nigeria for the period from 1970 to 2001.

Komain and Brahmasrene [21] examined the relationship between public expenditure and economic growth in Thailand, by employing the Granger causality test. The results revealed that public expenditure and economic growth are not cointegrated, but there exists a significant positive effect of public expenditure on economic growth. Barro [22] in a study of 98 developed and developing economies found a positive but weak relation between public expenditure and economic growth over the 1960 to 1985 period. Loizides and Vamvouks [23] employed the causality test to examine the relationship between public expenditure and economic growth, using data set on Greece, United Kingdom, and Ireland. The authors found that government size Granger causes economic growth in all the countries they studied. The results also indicated that economic growth Granger causes public expenditure for Greece and United Kingdom.

Bingxin et al. [24] assessed the impact of the composition of public expenditure on economic growth in developing countries. They used a dynamic generalized method of moment (GMM) model and a panel data set for 44 developing countries between 1980 and 2004. The results indicated that the various types of government spending had different impact on economic growth. In Africa, human capital expenditure contributes to economic growth whereas, in Asia, capital formation, agriculture, and education expenditure had strong growth promoting effect. In Latin America, none of the public expenditure items was significant impact on economic growth. Ramayandi [25] reviewed the relationship between government size and economic growth in the context of Indonesia and identified that government size tends to have a negative impact on growth.

Herath [5] examined the relationship between public expenditure and economic growth in Sri Lanka for the period from 1959 to 2003. The study found that government expenditure has a positive effect on economic growth; further his study suggested that openness is beneficial for Sri Lanka as 
it increases economic growth. Alam et al. [26] examined the long-run relationship between social expenditure and economic growth in Asian developing countries including Sri Lanka. According to the analysis the study concluded that expenditure in infrastructure, education, and health played an important role in promoting economic growth in all the selected Asian countries. Dilrukshini [4] studied the relationship between public expenditure and economic growth in Sri Lanka from 1952 to 2002 using time series data to test the validity of Wagner's law and found that there is no empirical support either for the Wagner's law or Keynesian hypothesis, in the case of Sri Lanka.

\section{Public Expenditure and Economic Growth in Sri Lanka}

Despite countries attempts to achieve its macroeconomic objectives through its fiscal and monetary policies, the effects of public expenditure in achieving fiscal policy goals of pursuing economic growth, equity, and maintaining macroeconomic stability have emerged as one of the great issue's in recent years. Following the political independence in 1948, the successive governments of Sri Lanka started to take the primary responsibility of building capital and infrastructure base to promote economic growth and social wellbeing of the people. This led the government to increase its spending on social and welfare activities. The outcomes of these activities also have reflected in many human development indicators in Sri Lanka. Following the economic liberalization, although Sri Lanka experienced with a number of external and domestic shocks, including global economic crisis, oil crisis, internal civil war, and natural disaster, it had recorded an average about five percent economic growth.

The trend of public expenditure as percentage of GDP in selected south Asian countries from 1990 to 2007 is shown in Table 1. In Bangladesh, total expenditure was only 12.4 percent of GDP in 1990s, and this was mere is increased to 14.3 percent in 2007. In India, during 1990s the expenditure was 17.3 percent while this was reduced up to 15.1 percent of GDP in 2007. It is also noted that the expenditure situation in Pakistan during 1990s was 25.9 percent, but this has slightly decreased to 19.3 percent in 2007. Therefore, the data presented in the above table clearly illustrate that public expenditure in Sri Lanka remains considerably the highest of its regional counterparts during last two decades.

Figure 1 shows the trend of public expenditure and economic growth in Sri Lanka over the period from 1960 to 2010. Despite public expenditure as a percentage of GDP shows downward trend, the total public expenditure in terms of rupees or dollars has shown an upward trend reflecting expansion of the overall government sector [27]. Furthermore, the rise in public expenditure and changes in the components of public expenditure have raised concerns regarding the sustainability of the growth process particularly after economic liberalization. The pattern in public expenditure in Sri Lanka since the 1980s has been mainly influenced by a change in role of the government in the growth process, financing pattern of the deficits (debt and interest payments), and the need for fiscal consolidation.
TABLe 1: Public expenditure (\% GDP) in South Asian countries.

\begin{tabular}{lcccc}
\hline Years & Sri Lanka & India & Pakistan & Bangladesh \\
\hline 1990 & 28.7 & 17.3 & 25.9 & 12.4 \\
1995 & 29.6 & 14.1 & 23.0 & 14.4 \\
2000 & 25.0 & 15.5 & 18.9 & 14.5 \\
2002 & 23.8 & 16.8 & 18.6 & 14.9 \\
2004 & 22.6 & 15.8 & 16.4 & 14.8 \\
2006 & 24.2 & 14.1 & 18.7 & 14.7 \\
2007 & 23.2 & 15.1 & 19.3 & 14.3 \\
\hline
\end{tabular}

Source: Key indicators of Asia and Pacific; Asian Development Bank 2008.

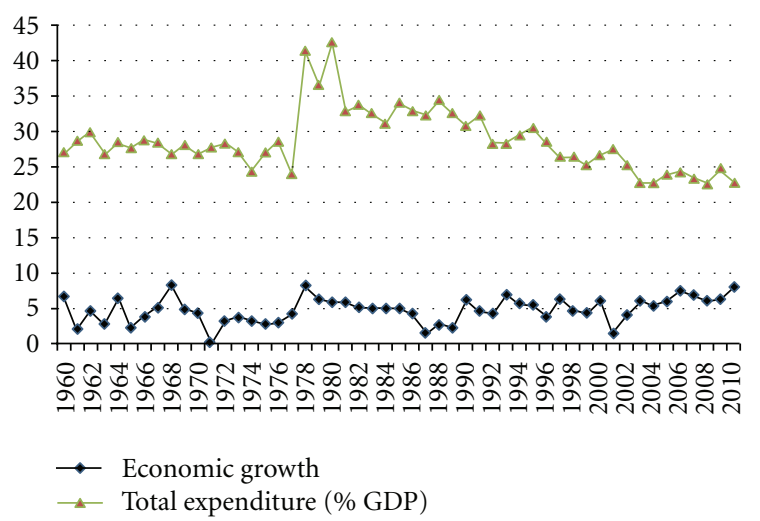

FIGURe 1: Public expenditure (\% GDP) and economic growth in Sri Lanka, 1960-2010. Source: [27].

In this regard, with a view to understand as to how public expenditure plays as a central instrument in promoting economic growth, it is also useful to analytically classify the various components of public expenditure in terms of their influence on various segments of economy. Public expenditure can be classified under two categories, namely, current expenditure and capital expenditure. Current expenditure represents the consumption while the capital expenditure represents asset creation by the government. These expenditures are also classified in terms of developmental and nondevelopmental categories so as to assess their welfare impact. The developmental expenditure mainly includes expenditure on economic services such as agriculture, industry, energy, communication, transport, science, technology, environment, and so on, and social services including education, health, employment, nutrition, housing, and so on. The remaining categories such as government administration, interest payments, pensions, defense, and other nonproductive services constitute nondevelopmental expenditure. The economic growth is normally more responsive to developmental expenditure.

Moreover, not only the total size but also the composition of public expenditures is also very important because different components of expenditure exercise a different impact on growth and development and social welfare. Similarly, changes in composition are also an important determinant of the efficiency in resource allocation. In the context of Sri Lanka, although it has experienced an increasing trend 
in public expenditure following the political independent, the pattern of the composition of expenditure has changed dramatically over the period. Table 2 shows the average share of the public expenditure in Sri Lanka on selected components including education, defense, health, agriculture, and transport and communication during the period from 1980 to 2010 and shows the fluctuation over the periods.

Economic growth is vital for sustainable development. Improvements in infrastructure, health, housing, education, and agricultural productivity enhance the living standard of people. Similarly, by addressing the nation's principal needs, these sectors are playing crucial role in stimulating growth and development of an economy. As noted in the above table, following the economic liberalization, the share of defense expenditure started to increase while the share of other sector's expenditure decreased considerably. In 1980-1985 period, the share of defense expenditure as a percentage of total expenditure was 3.04 percent while it increased to 16.07 percent by $1996-2000$ period, and in 2006-2010 period the share of this expenditure was slightly decreased to 11.81 percent. At the same time, the share of agriculture expenditure decreased to 5.04 percent in 20062010 period from 17.47 percent in $1980-1985$ period. On the other hand, the share of education expenditure was increased from 7.28 percent in $1980-1985$ period to 9.52 percent in 2006-2010 period. In comparison to the defense expenditure this was increased by 31 percent whereas defense expenditure increased by 289 percent. Moreover, government expenditure as a percentage of total expenditure on transport and communication sector also declined from 8.33 percent in 1980-1985 to 6.56 percent in 2001-2005. However during 2006-2010 period this expenditure increased to 11.45 percent of the total expenditure. Therefore, it is evident that during 1980-2009 period the defense expenditure dominated all other expenditure categories accounting average about 10.26 of total expenditure, which is not surprising given the civil war situation in the country. Secondly, expenditure in education sectors shows the highest allocation since successive governments of Sri Lanka recognized the role of education in development and therefore devoted much public resources to this sector. On the other hand, due to higher private sector participation in health care activities, public expenditure on health sector remained averaged about 1.5 percent of the GDP. Furthermore, both agriculture and transport and communication expenditures were recorded nearly about 7.7 percent and 8.82 percent of total public expenditure, respectively.

\section{Data and Methodology}

This study uses time series annual data over the period from 1960 to 2010. The data sources for public expenditure, government consumption expenditure, gross domestic product, and population have been obtained from various issues of the annual report of the Central Bank of Sri Lanka. Similarly, to neutralize the impact of increase or decrease in prices, all the variables have been deflated at 1996 prices by using appropriate deflators. Moreover, for estimating the relative elasticity, the natural logarithms of all the variables have
TABLe 2: Public expenditure in selected components (\% total expenditure).

\begin{tabular}{lccccc}
\hline Period & DEF & EDU & HEL & AGR & TRC \\
\hline $1980-1985$ & 3.04 & 7.28 & 4.09 & 17.47 & 8.33 \\
$1986-1990$ & 6.93 & 8.66 & 4.96 & 11.02 & 10.65 \\
$1991-1995$ & 11.77 & 9.53 & 5.11 & 5.13 & 8.58 \\
$1996-2000$ & 16.07 & 9.70 & 5.54 & 3.84 & 7.35 \\
$2001-2005$ & 11.96 & 9.13 & 6.50 & 3.71 & 6.56 \\
2006-2010 & 11.81 & 9.52 & 7.02 & 5.04 & 11.45 \\
\hline Average & 10.26 & 8.97 & 5.54 & 7.70 & 8.82 \\
\hline
\end{tabular}

Source: [27].

DEF: defense, EDU: education, HEL: health, AGR: agriculture, and TRC: transport and communication.

been utilized (An advantage of grouping the above variables in natural logarithmic form is to achieve stationarity in the lower order of integration in case the logs of these variables are nonstationary at levels). Engle and Granger [28] twostep residual based cointegration approach has been used to test the validity of Wagner's hypothesis in Sri Lanka. Generally, most of the time series variables are nonstationary, containing a unit root [29]. Therefore, in this situation, a standard regression with nonstationary data can lead to the problem of spurious (spurious problem can occur when two time series variables in a regression are highly correlated whereas there is no actual relationship between them. High correlation is due to the existence of time trend in both time series variables [30]). In an attempt to avoid the spurious problem, the difference of the variables has to be included for the cointegration analysis.

The first step for cointegration test is to examine the stationery properties of all the variables. The Augmented Dickey Fuller (ADF) and Phillips Perron (PP) tests are employed to examine the properties of the time series variables and to determine the order of integration for each series in this study. If all the variables are found to be integrated of the same order (the order of integration can be defined as the number of time a time series variable must be differeniated for it to become stationary.), the second step is to apply the OLS method to the regression equation (1) to test for the long-run relationship between GDP and PEX. Consider

$$
\operatorname{PEX}_{t}=a_{0}+b_{0} \mathrm{GDP}_{t}+u_{t}
$$

where GDP is the gross domestic product, PEX is the public expenditure, $a_{0}$ and $b_{0}$ are the parameters known as the intercept and slope coefficient, and $u$ is the random disturbance term. As per this regression equation, in order to confirm the validity of Wagner's law, the growth elasticity of public expenditure values should exceed unity and more than zero for absolute and relative versions, respectively.

If we find evidence of a long-run relationship, we then estimate the error correction model (ECM), which incorporates variables both in their levels and first difference and captures the short-run disequilibrium situations as well as 
TABLE 3: ADF and PP unit root test.

\begin{tabular}{|c|c|c|c|c|c|}
\hline \multirow{2}{*}{ Variables } & \multicolumn{2}{|c|}{ Augmented dickey fuller (ADF) } & \multicolumn{2}{|c|}{ Phillip Perron (PP) } & \multirow{2}{*}{ Decision (order of integration) } \\
\hline & Level & First difference & Level & First difference & \\
\hline GDP & -1.192 & $-11.721^{*}$ & -2.752 & $-16.827^{*}$ & $\mathrm{I}(1)$ \\
\hline NEXP & -1.612 & $-5.161^{* *}$ & -1.336 & $-2.612^{* *}$ & $\mathrm{I}(1)$ \\
\hline RPCEXP & 0.835 & $-5.937^{*}$ & 0.657 & $-5.937^{*}$ & $\mathrm{I}(1)$ \\
\hline REXP & 0.952 & $-5.848^{*}$ & 0.766 & $-5.847^{*}$ & $\mathrm{I}(1)$ \\
\hline RGDP & -1.612 & $-2.626^{* *}$ & 0.762 & $-6.681^{*}$ & $\mathrm{I}(1)$ \\
\hline RPCGDP & -1.612 & $-2.625^{* *}$ & 0.613 & $-6.818^{*}$ & $\mathrm{I}(1)$ \\
\hline
\end{tabular}

$*, * *, * *$ are significant at one percent, five percent and ten percent level.

GDP: gross domestic product, NEXP: nominal expenditure, RPCEXP: real per-capita expenditure, REXP: real expenditure, RGDP: real GDP, RPCGDP: real per-capita GDP.

TABLE 4: Cointegration regression.

\begin{tabular}{|c|c|c|c|}
\hline Model & Version & $\begin{array}{l}\text { Intercept } \\
\quad\left(a_{0}\right)\end{array}$ & $\begin{array}{l}\text { Long-run income } \\
\text { elasticity } \\
\left(b_{0}\right)\end{array}$ \\
\hline 1 & $\begin{array}{l}\text { Peacock and } \\
\text { Wiseman [7] }\end{array}$ & $-1.833(0.932)$ & $0.904^{* *}(0.000)$ \\
\hline 2 & Gupta [8] & $6.411(0.955)$ & $1.023^{* *}(0.000)$ \\
\hline 3 & Goffman [9] & $-17.177(0.459)$ & $7.523^{* *}(0.000)$ \\
\hline 4 & Pryol [10] & $7.243(0.363)$ & $0.861^{* *}(0.000)$ \\
\hline 5 & $\begin{array}{l}\text { R. A. Musgrave and } \\
\text { P. B. Musgrave [1] }\end{array}$ & $28.833 *(0.036)$ & $-0.061^{* *}(0.000)$ \\
\hline 6 & Mann [11] & $28.805^{*}(0.039)$ & $-2.941^{* *}(0.000)$ \\
\hline
\end{tabular}

Figures in parentheses represent the $P$ value of the respective coefficient in the estimated regression.

TABLE 5: Unit root test for residuals.

\begin{tabular}{lccc}
\hline Model & Variables & Level & Order of integration \\
\hline 1 & Error term 1 & $-10.145^{*}$ & $\mathrm{I}(0)$ \\
2 & Error term 2 & $-10.073^{*}$ & $\mathrm{I}(0)$ \\
3 & Error term 3 & $-9.926^{*}$ & $\mathrm{I}(0)$ \\
4 & Error term 4 & $-10.734^{*}$ & $\mathrm{I}(0)$ \\
5 & Error term 5 & $-10.324^{*}$ & $\mathrm{I}(0)$ \\
6 & Error term 6 & $-10.776^{*}$ & $\mathrm{I}(0)$ \\
\hline$*, * *, * *$ & are significant at one percent, five percent, and ten percent level.
\end{tabular}

the long-run equilibrium adjustments between the variables. As per this study, the ECM specification is given as follows:

$$
\begin{gathered}
\Delta \mathrm{PEX}_{t}=\alpha_{0}+b_{0} \Delta \mathrm{GDP}_{t}+b_{1} u_{t-1}+u_{t} \\
\Delta \mathrm{PEX}_{t}=\mathrm{PEX}_{t}-\mathrm{PEX}_{t-1}, \quad \Delta \mathrm{GDP}_{t}=\mathrm{GDP}_{t}-\mathrm{GDP}_{t-1}
\end{gathered}
$$

where $\Delta$ denotes the first difference operator, $u_{t}$ is a random error term, and $u_{t-1}$ is the one-period lagged value of the error from the cointegrating regression. The above error correction model states that $\triangle$ PEX depends on $\triangle$ GDP and also on the equilibrium error term. Where $b_{0}$ and $b_{1}$ are parameters to be estimated and while $b_{0}$ measures the immediate impact of a change in GDP on a change in PEX; $b_{1}$ indicates a direct convergence to long-run equilibrium.

\begin{tabular}{|c|c|c|c|c|}
\hline Model & Version & $\begin{array}{l}\text { Intercept } \\
\quad\left(a_{0}\right)\end{array}$ & $\begin{array}{c}\text { Short-run income } \\
\text { elasticity } \\
\left(b_{0}\right)\end{array}$ & $\begin{array}{l}\text { Error term } \\
\qquad\left(b_{1}\right)\end{array}$ \\
\hline 1 & $\begin{array}{l}\text { Peacock and } \\
\text { Wiseman [7] }\end{array}$ & $\begin{array}{l}9.451^{*} \\
(0.000)\end{array}$ & $\begin{array}{l}0.209^{*} \\
(0.000)\end{array}$ & $\begin{array}{c}-0.324^{*} \\
(0.000)\end{array}$ \\
\hline 2 & Gupta [8] & $\begin{array}{l}0.051^{*} \\
(0.000)\end{array}$ & $\begin{array}{l}0.208^{*} \\
(0.000)\end{array}$ & $\begin{array}{c}-0.253^{*} \\
(0.000)\end{array}$ \\
\hline 3 & Goffman [9] & $\begin{array}{r}13.451^{*} \\
(0.000)\end{array}$ & $\begin{array}{r}42.269^{*} \\
(0.000)\end{array}$ & $\begin{array}{c}-0.707^{*} \\
(0.000)\end{array}$ \\
\hline 4 & Pryol [10] & $\begin{array}{l}0.139 * \\
(0.000)\end{array}$ & $\begin{array}{c}-0.091^{*} \\
(0.000)\end{array}$ & $\begin{array}{c}-0.003^{*} \\
(0.000)\end{array}$ \\
\hline 5 & $\begin{array}{l}\text { R. A. Musgrave } \\
\text { and P. B. } \\
\text { Musgrave [1] }\end{array}$ & $\begin{array}{l}0.435^{*} \\
(0.000)\end{array}$ & $\begin{array}{l}0.136^{*} \\
(0.000)\end{array}$ & $\begin{array}{c}-0.431^{*} \\
(0.000)\end{array}$ \\
\hline 6 & Mann [11] & $\begin{array}{l}0.131^{*} \\
(0.000)\end{array}$ & $\begin{array}{c}-4.251^{*} \\
(0.000)\end{array}$ & $\begin{array}{r}-0.454^{*} \\
(0.000)\end{array}$ \\
\hline
\end{tabular}

TABLE 6: Error correction model (ECM).

$*, * *, * *$ are significant at one percent, five percent, and ten percent level. Figures in parentheses represent the $P$ value of the respective coefficient in the estimated regression.

The next step of the estimation is to test the causality among the variables. For this purpose, the causal direction framework developed by Granger (1969) and Sims (1972) has been used (the systematic testing and determination of causal direction framework developed by Granger (1969), and Sims (1972) are simply based on the axiom that past and present may cause the future, but the future cannot cause the past [31]). The Granger causality test will be run based on the following equations:

$$
\begin{aligned}
\Delta Y_{t} & =\alpha+\sum_{i=1}^{m} \beta_{\mathrm{i}} \Delta Y_{t-1}+\sum_{j=1}^{n} \beta \varphi_{i} \Delta X_{t-1}+\varepsilon_{t}, \\
\Delta X_{t} & =\chi+\sum_{i=1}^{m} \phi_{i} \Delta X_{t-1}+\sum_{j=1}^{n} \mu_{i} \Delta Y_{t-1}+v_{t}
\end{aligned}
$$

where $Y_{t}$ and $X_{t}$ are two stationary series and $i$ and $j$ stand for lag lengths. The unilateral causality exists when $Y_{t}$ is said to be Granger caused by $X_{t}$ which means that the coefficients on the lagged of $X_{t}$ are statistically significant. On the other hand, a bilateral causality is said to exist when 
TABLE 7: Granger causality test.

\begin{tabular}{|c|c|c|c|c|c|}
\hline Model & Null hypothesis & Lag & Obs & F Stat & Prob. \\
\hline \multirow{2}{*}{1} & RGDP does not Granger cause REXP & \multirow{2}{*}{2} & \multirow{2}{*}{48} & 0.0012 & 0.9998 \\
\hline & REXP does not Granger cause RGDP & & & 0.4928 & 0.6142 \\
\hline \multirow{2}{*}{2} & RPCGDP does not Granger cause RPCEXP & \multirow{2}{*}{2} & \multirow{2}{*}{48} & 0.8731 & 0.4631 \\
\hline & RPCEXP does not Granger cause RPCGDP & & & 0.0082 & 0.9989 \\
\hline \multirow{2}{*}{3} & REXP does not Granger cause RPCGDP & \multirow{2}{*}{2} & \multirow{2}{*}{48} & 1.3521 & 0.2692 \\
\hline & RPCGDP does not Granger cause REXP & & & 0.0648 & 0.9919 \\
\hline \multirow{2}{*}{4} & CEXP does not Granger cause RGDP & \multirow{2}{*}{2} & \multirow{2}{*}{48} & 7.8776 & 0.1021 \\
\hline & RGDP does not Granger cause CEXP & & & 22.6554 & 1.9907 \\
\hline \multirow{2}{*}{5} & RPCGDP does not Granger cause (NEXP/NGDP) & \multirow{2}{*}{2} & \multirow{2}{*}{48} & 0.0661 & 0.9360 \\
\hline & (NEXP/NGDP) does not Granger cause RPCGDP & & & 0.2522 & 0.7782 \\
\hline \multirow{2}{*}{6} & RGDP does not Granger cause (NEXP/NGDP) & \multirow{2}{*}{2} & \multirow{2}{*}{48} & 0.0636 & 0.9386 \\
\hline & (NEXP/NGDP) does not Granger cause RGDP & & & 0.2284 & 0.7967 \\
\hline
\end{tabular}

$*, * *, * *$ are significant at one percent, five percent, and ten percent level.

both coefficients are statistically significant, and there is independence when both are statistically insignificant.

\section{Results and Discussion}

The first step of Engle and Granger Cointegration approach is to test the presence of unit root in time series variables. Augmented Dickey Fuller (ADF) and Phillips Perron (PP) tests have been used to determine the existence of unit root in the time series data. Table 3 presents the results of ADF and $\mathrm{PP}$ test. Both tests results reveal that the time series variables incorporated in this study exhibit consistent trend over the period. This implies that they accept the null hypothesis of nonstationery in levels. However, when ADF and PP tests are applied to the transformed series of each variable to check for the possibility of stationarity in first differences, the null hypothesis at first difference is rejected and reveals that all the variables become stationery.

Since all the variables are integrated of the same order, the cointegration approach suggested by Engle and Granger [28] was applied to investigate the long-run relationship between public expenditure and economic growth on all six versions of the Wagner's law. The Engle and Granger cointegration test results as shown in Table 4. Empirically, the real income elasticity for all versions except Gupta [8], Goffman [9], and Mann [11] is less than one. These results suggest that Wagner's law does not exist in case of Sri Lanka.

The findings of this study relating to public expenditure and Gross Domestic Product (GDP) are consistent with the findings of Dilrukshini [4] where she studied the relationship between public expenditure and economic growth in Sri Lanka from 1952 to 2002 period using time series data and found that there is no empirical support either for the Wagner's law or Keynesian hypothesis, in the case of Sri Lanka.

The ADF and PP unit root test for residuals is presented in Table 5. The results show that the residuals in all six models are integrated of order-zero I (0). Therefore, it suggests that the dependent and independent variables are cointegrated, and thus a valid and stable long-run relationship exists among the variables considered.

The short-run dynamics of the error correction model (ECM) is presented in Table 6. The results show that the estimated error correction term is significant at 1 percent level for all six versions of the Wagner's law and carries a significant negative sign, indicating that in Sri Lanka public expenditure and gross domestic product (GDP) are cointegrated. It also shows that 71 percent of the deviation of the real GDP from its long-run equilibrium level is corrected each year in model 3 , while other five models indicate $-0.324,0.253,0.003,0.431$, and 0.454 , respectively.

The Granger causality test is conducted for all six models using two lags to examine the lead-lag relationship among the variables incorporated in this study. The results are reported in Table 7 . The reported results reveal that none of the variables found to Granger causes growth rate of real output in pairs and jointly. Therefore, the empirical result confirmed that Wagner's law, which suggests that the share of the public sector in the economy will rise as the economic growth proceeds, does not exist in case of Sri Lanka. However, this study can be further extended in future by considering the composition of public expenditure and economic growth in Sri Lanka which can help the policy makers to make a deeper understanding on the relationship between public expenditure and economic growth.

\section{Conclusion}

This study examined the validity of Wagner's law in case of Sri Lanka over the period from 1960 to 2010 . To assess the responese of public expenditure in increasing gross domestic product (GDP), this study considered six models of Wagner's law, namely, Peacock and Wiseman [7], Gupta [8], Goffman [9], Pryol [10], R. A. Musgrave and P. B. Musgrave [1], and 
Mann [11]. ADF and PP tests results reveal that the time series variables incorporated in this study exhibit consistent trend over the period, and they accept the null hypothesis of nonstationery in levels. However, the null hypothesis at first difference is rejected and reveals that all the variables become stationery. The Engle and Granger cointegration test results showed the existence of long-run relationship between GDP and public expenditure. Despite the empirical evidence in the paper shows the existence of long-run relationship between GDP and public expenditure, the real income elasticity for all versions except Gupta [8], Goffman [9], and Mann [11] is less than one. The findings, therefore, lend no support to the theoretical prediction that the share of the public sector in the economy would play an important role in enhancing economic growth in Sri Lanka. This result confirmed that Wagner's law, which suggests that the share of the public sector in the economy will rise as economic growth proceeds, does not exist in case of Sri Lanka. Granger causality test has also been consistent with these findings. However, the findings of this study pave to broaden this study further for a deeper understanding about the relationship between public expenditure and economic growth by giving more attention on composition of public expenditure and by including more macroeconomic variables in the econometric model using different methodology in future.

\section{References}

[1] R. A. Musgrave and P. B. Musgrave, Public Finance: In Theory and Practice, Mc-Graw-Hill International, NewYork, NY, USA, 1989.

[2] A. Wagner, "Extracts on public financ," in Classics in the Theory of Public Finance, R. A. Musgrave and A. T. Peacock, Eds., Macmillan, London, UK, 1958.

[3] J. M. Keynes, General Theory of Employment, Interest and Money, Harcourt, Brace and Co, New York, NY, USA, 1936.

[4] W. A. Dilrukshini, "Expenditure and economic growth in Sri Lanka: co-integration analysis and causality testing," Staff Studies, vol. 34, pp. 51-68, 2004.

[5] S. Herath, "Size of the government and economic growth: an Empirical Study of Sri Lanka," SRE-Discussion Papers 2010/05, WU Vienna University of Economics and Business, Vienna, Austria, 2010.

[6] R. M. Bird, "Wagner's law of expanding state activity," Public Finance, vol. 26, no. 1, pp. 1-26, 1971.

[7] A. T. Peacock and J. Wiseman, Growth of Public Expenditure in the United Kingdom, NBER and Princeton: Princeton University Press, Cambridge, UK, 1961.

[8] S. P. Gupta, "Expenditure and economic growth: a time series analysis," Public Finance, vol. 22, no. 4, pp. 111-120, 1967.

[9] C. W. J. Goffman, "On the empirical testing of wagner's law: a technical note,” Public Finance, vol. 23, no. 3, pp. 359-364, 1968.

[10] F. L. Pryol, Public Expenditure in Communist and Capitalist Nations, George Allen and Unwin, London, UK, 1969.

[11] A. J. Mann, "Wagner's law: an econometric test for Mexico, 1925-1976," National Tax Journal, vol. 33, no. 2, pp. 189-201, 1980.

[12] K. D. Ranjan and C. Sharma, "Expenditure and economic growth: evidence from India," The ICFAI University Journal of Public Finance, vol. 6, no. 3, pp. 60-69, 2008.
[13] B. Singh and B. S. Sahni, "Causality between public expenditure and national income," The Review of Economics and Statistics, vol. 66, no. 4, pp. 630-644, 1984.

[14] F. G. Castles and S. Dowrick, "Impact of government spending levels on medium term economic growth in the OECD, 19601985," Journal of Theoretical Policies, vol. 2, pp. 173-204, 1990.

[15] S. Devarajan, V. Swaroop, and H. F. Zou, "The composition of public expenditure and economic growth," Journal of Monetary Economics, vol. 37, no. 2, pp. 313-344, 1996.

[16] E. Dogan and T. C. Tang, "Government expenditure and national income: causality tests for five south East Asian countries," International Business and Economic Research Journal, vol. 5, no. 10, 2006.

[17] S. Verma and R. Arora, "The Indian economy support Wagner's law? An econometric analysis," Eurasian Journal of Business and Economics, vol. 3, no. 5, pp. 77-91, 2010.

[18] M. Afzal and Q. Abbas, "Wagner's law in Pakistan: another look," Journal of Economics and International Finance, vol. 2, no. 1, pp. 12-19, 2012.

[19] Y. Zheng, J. Li, X. L. Wong, and C. Li, "An empirical analysis of the validity of Wagner's law in China: a case study based on Gibbs sampler," International Journal of Business and Management, vol. 5, no. 6, 2010.

[20] P. A. Olomola, "Cointegration analysis-causality testing and Wagner's law: the case of Nigeria," Journal of Social and Economic Development, vol. 6, no. 1, pp. 76-90, 2004.

[21] J. Komain and T. Brahmasrene, "Relationship between government expenditures and economic growth in Thailand," Journal of Economics and Economic Education Research, vol. 8, no. 1, pp. 93-102, 2007.

[22] R. J. Barro, "Economic growth in a cross section of countries," Quarterly Journal of Economics, vol. 106, no. 2, pp. 407-443, 1991.

[23] J. Loizides and G. Vamvoukas, "Expenditure and economic growth: evidence from trivariate causality testing," Journal of Applied Economics, vol. 8, pp. 125-152, 2005.

[24] B. Yu, S. Fan, and A. Saurkar, "Does composition of government spending matter to economic growth?" in Proceedings of the International Association of Agricultural Economists Conference, Beijing, China, August 2009, http:// ageconsearch.umn.edu/bitstream/51684/2/IAAE\%20government\%20spending.pdf.

[25] A. Ramayandi, "Growth and government size in Indonesia: some lessons for the local authorities," Working Papers in Economics and Development Studies 2003/02, Department of Economics, Padjadjaran University, 2003.

[26] S. Alam, A. Sultana, and M. S. Butt, "Does social expenditures promote economic growth? A multivariate panel cointegration analysis for Asian Countries," European Journal of Social Sciences, vol. 14, no. 1, pp. 44-54, 2010.

[27] Central Bank of Sri Lanka, Annual Reports, Various Years.

[28] R. F. Engle and C. W. J. Granger, "Cointegration and error correction: representation, estimation, and testing," Econometrica, vol. 55, no. 2, pp. 251-276, 1987.

[29] D. Gujarati, Basic Econometrics, Mc.Graw-Hill International Edition, NewYork, NY, USA, 3rd edition, 1995.

[30] C. W. J. Granger and P. Newbold, "Spurious regressions in econometrics," Journal of Econometrics, vol. 2, no. 2, pp. 111120, 1974.

[31] C. W. J. Granger, "Some properties of time series data and their use in econometric model specification," Journal of Econometrics, vol. 16, no. 1, pp. 121-130, 1981. 


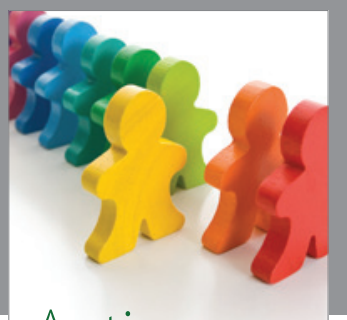

Autism

Research and Treatment
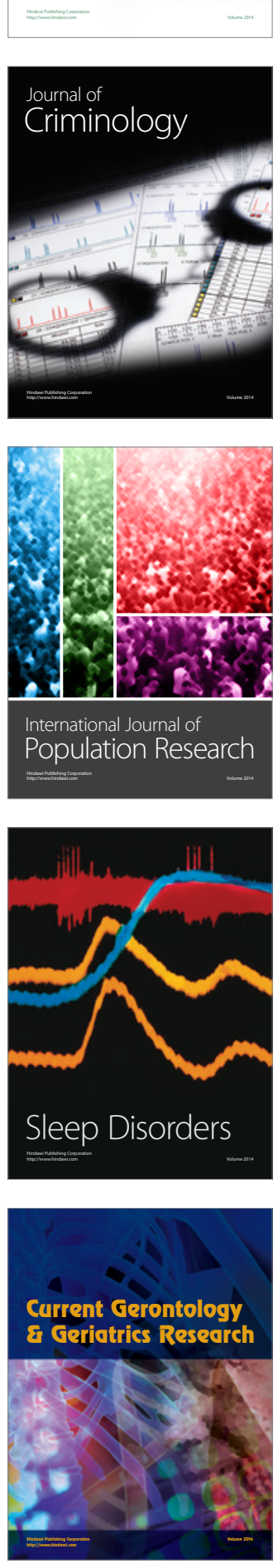
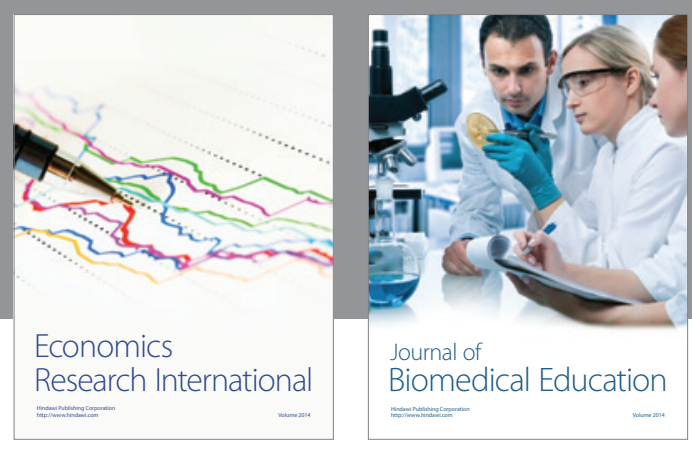

Journal of

Biomedical Education

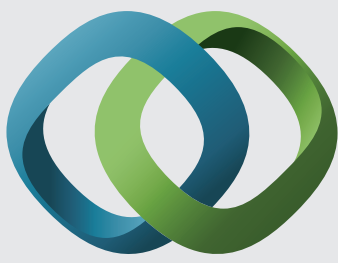

\section{Hindawi}

Submit your manuscripts at

http://www.hindawi.com
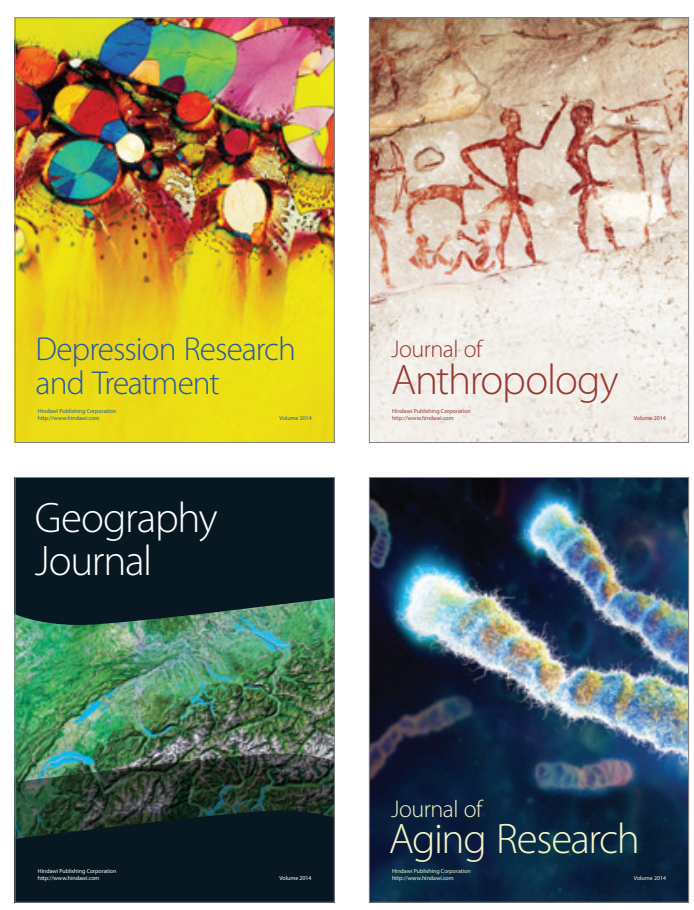

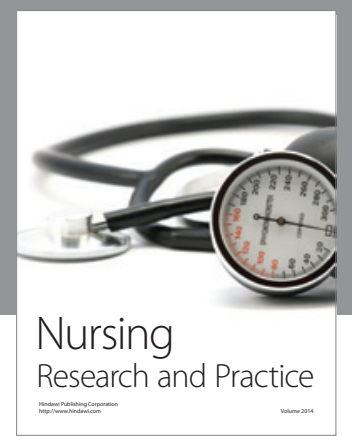

Nursing

Research and Practice

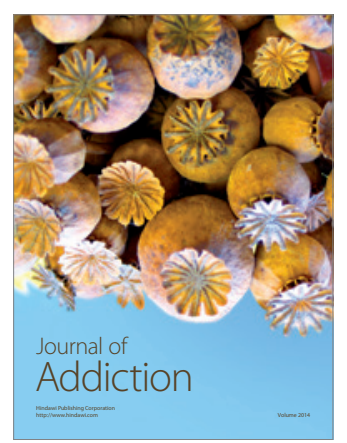

Child Development

Research

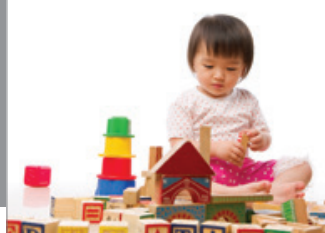

迥
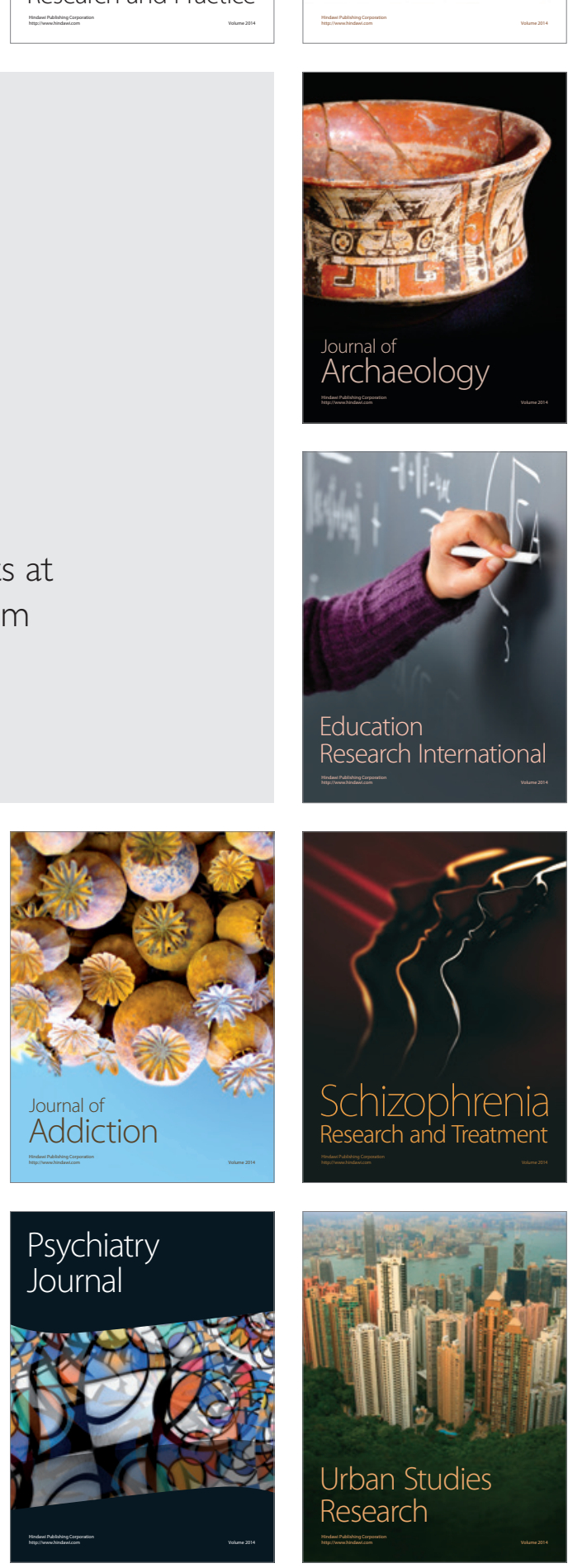